\title{
Rammed earth walls in Serón de Nágima castle (Soria, Spain): Constructive lecture
}

\author{
I.J. Gil Crespo \\ Polytechnic University of Madrid, Spain
}

\begin{abstract}
The Raya or frontier between the kingdoms of Castile and Aragón was fortified with a system of castles and walled-cities that were useful during the several conflicts that took place in the Late Medieval Age. The Serón de Nágima castle defended the communication road between the axis of the Jalón river valley, which flows into the Ebro, and Duero valley. Its uniqueness stems from the fact that it is one of the few fortifications in the area where rammed earth is the only building system used. In this paper, the castle building fundaments are exposed mainly focusing on the techniques and building processes developed from the interpretation of the legible constructive signs in its walls.
\end{abstract}

\section{INTRODUCTION}

The Late Medieval strategy for delimitating and defending the frontier between Castile and Aragón was in its systematic fortification. Ancient castles and Muslim fortifications were repaired and new buildings for defense were erected. The aim of the author's Doctoral Thesis, which gathers from the present paper, is to know the construction techniques of a selection of these castles, so as to interpret the building activity of that historical moment and analyze the systematization of these construction techniques within the historical, geographical and architectural context. The research method consists of a fieldwork in which a series of castles are documented and surveyed; they are previously selected after analyzing the bibliographical works of the medieval Soria's castellology. An extensive table has been compiled with all fortified elements of the province, which includes basic historical, typological, building and bibliographical data. With the data collected on site, the analysis of the construction of each element is developed (about 30 have been selected and documented), supported by graphical and computer resources.

Many of these castles were built using the rammed earth, as the case of the castles of Serón de Nágima and Yanguas. In other occasions, there are only some walls of the castle which were built with this constructive technique. We can observe this item in the castles of Caracena and Berlanga de Duero. Finally, we have noticed that the rammed earth was used as filler in the walls with a masonry external layer, for example in the castles of La Raya, Arcos de Jalón or Ágreda. Through the constructive putlog holes left in the masonry by the scaffolding we can study the systems and processes of building. The architectonical lecture of these putlog holes reveals to us the auxiliary methods and the constructive processes.

This paper presents the study of the fortress of Serón de Nágima. This castle is, along with the castle of Yanguas, the only case in which rammed earth is the only technique used for building the walls in the province of Soria.

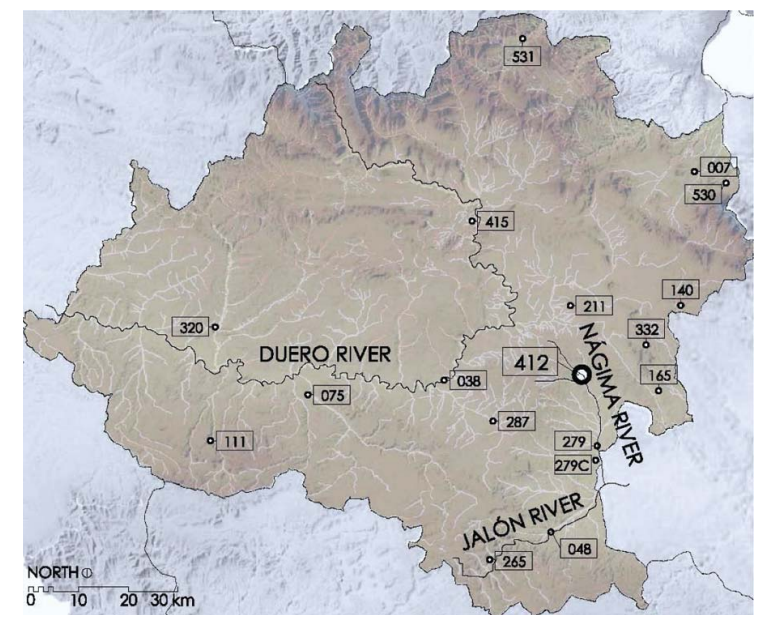

Figure 1. Situation map where are signed the places named in the paper: Ágreda (007), Almazán (038), Arcos de Jalón (048), Berlanga de Duero (075), Caracena (111), Ciria (140), Deza (165), Gómara (211), Medinaceli (265), Monteagudo de las Vicarías (279), Morón de Almazán (287), Osma (320), Peñalcázar (332), La Raya (279C), Serón de Nágima (412), Soria (415), Vozmediano (530) and Yanguas (531). 


\section{THE FRONTIER FORTIFICATION}

The current provincial administrative boundaries, due to their arbitrariness and sometimes lack of consistency with the historical frontiers, are not usually suitable for historical researches. However, the strip of land that forms the geographical framework of the research has been a historical frontier in which there has been effort to define since the Reconquest. Furthermore, one of the Castilian monarchs' concerns was the definition and defense of the border with Aragón, because of the constant wars between the two Spanish Crowns throughout the Late Medieval.

The administrative territory which the current Soria occupies since 1833 has been a transit and border territory since antiquity. Celtiberian culture experienced its greatest development here. The desire of Rome to control this territoryfor example, the famous and extensive siege of Numancia-responded to the need to control such an important way between the river Ebro and the river Duero Valleys.

However, the character of passage and communication road between these large geographic features - the Ebro, the Duero and the Tajo valley-turns into a border as the Reconquest takes place. The Reconquest of the Duero Valley develops along the 10th Century, when the western part of the current province is taken. The Islamic Marca Media-Middle Mark, an Islamic administrative territorial division - establish its frontier in the Duero, and for its surveillance they built up a complete network of atalayas or watchtowers. In $946 \mathrm{Abd}$ al-Rahman III rebuilds and fortifies the town of Medinaceli, where he moves the capital of the Marca Media in reaction to the Christians advance and so as to control the Jalón River, an extremely important communication channel between the main cities as «sentry against Castile» (Rubio Semper 1990, 115-116). Castile advances through the south and in 1104 conquer Medinaceli.

Meanwhile, Alfonso I of Aragón conquered Zaragoza, the eastern of Soria in the early 12th Century. In 1124 he reaches the upper Jalón until Medinaceli. The concern of Alfonso I, named Batallador - the Battler-, after conquering these territories was to control them. His political plan was to repopulate and organize the new conquered lands. In order to achieve this, he kept the Muslims who were already in these lands and brought Mozarabic Levantine people. Alfonso I the Battler, King of Aragón, had married Lady Urraca, who succeeded to the throne of Castile his father Alfonso VI of Castile and León between 1109 and 1126. Under his reign, Aragón advanced from the Ebro's valley thanks to the conquest of
Zaragoza in 1118. A year later he reaches Soria, seizing power of the eastern of the province. He repopulated Soria territories, the Vicarías, Morón, Almazán, Serón, Ciria and Ágreda. When he later divorces his wife, he kept the land under the government of Aragón. These lands are soon claimed by Alfonso VII, king of Castile and emperor of León who reigned from 1126 to 1157, Urraca's son and the stepson of the Aragonese king. He seized the Regnum Caesaraugustanum (Zaragoza, Tarazona, Calatayud and Daroca) and returned them after the Carrión's Treaty in 1140, to the recently formed Kingdom of Aragón, in exchange for the vassalage of Ramón Berenguer IV. Later, in 1296, Alfonso de la Cerda reaches Soria lands with Enrique de Aragón help and proclaims himself king of Castile, after taking possession of Serón, Soria, Osma, Almazán and Deza. With the Treaty of Tarazona and Huerta they are returned in 1328 (Zamora Lucas 1969, 30-31; Torres Fontes 1987).

With these border disputes and frictions among other reasons, a series of struggles begin between the two crowns which would not cease until the late Middle Age. The most important was the "Guerra de los Dos Pedros"-Two Peters War - in the 14th Century (Diago Hernando 1998, 125-156).

When Castile, halfway through the twelfth century, the Muslim population is expelled from Calatayud to Sigüenza, establishing Communities of Villa y Tierra - Town and Country-and repopulating with people brought from the Lara's alfoz: from Biscay and Burgos.

These communities of Villa y Tierra were transformed into lordship lands as a means of guarding the borderlands. The Crown must appoint fronteros - a kind of frontier knights - in villages near the borders so as to monitor these disputed regions, who were responsible for raising and reforming military fortresses and buildings, which are nowadays located in the east of the province of Soria, in the mentioned above regions, which constitute the scope of the investigation.

\section{STATE OF THE ART}

The historical elements that merge in the castle of Serón de Nágima were collected by Florentino Zamora Lucas, who was a Soria's castellology expert. In 1969 he publishes an article in the Journal Castillos de España (Bulletin of the Spanish Association of Castles Friends) in which he compiles the known historical facts known about this fortress and Vozmediano one. However, it offers no details about its construction. These same data are collected by the same author in the encyclopedic work Corpus de los castillos medievales de Castilla (Espinosa de los Monteros \& Martin-Artajo 
Saracho 1974, 456-461). There are several books about the castles of the province of Soria in which this castle appears (Casa Martinez et al., 1990, 66; Lorenzo Celorrio 2003, 197-200; Bernad Remón 1994, 50-51), although they don't show any further information besides the already given by Zamora Lucas. Finally, Fraile Delgado studies the construction material of the fortress of Serón in his doctoral thesis (Fraile Delgado 2005, ch. 5, 6-14, ch. 9, 19-23). This is the latest research-and, constructively, the most complete - about the castle of Serón de Nágima.

\section{HISTORICAL ELEMENTS}

In the river Nágima's valley, between Ariza and Gómara, over a hill near the intersection of the river Carraserón or Valdevelilla stream, lie the each time scanter rests of the Serón de Nágima's fortress.

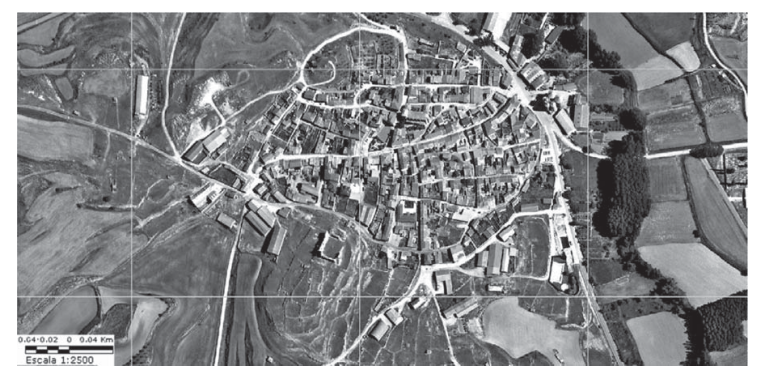

Figure 2. Ortophotography of the village of Serón de Nágima. In the southern part, on a hill which dominates the houses, there are the ruins of the castle (IDECyL 2011).

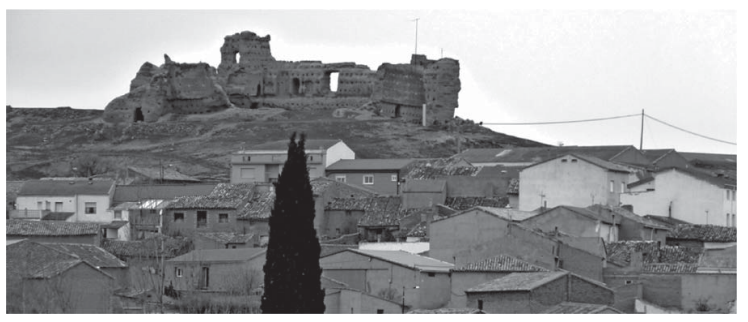

Figure 3. General north-east view. The castle over the village.

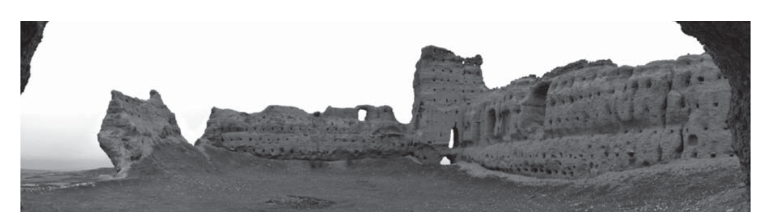

Figure 4. Inner view of the castle.
There are no clear evidences about its foundation. Several authors date its construction during the Muslim domination (Zamora Lucas 1969, 30; Lorenzo Celorrio 2003, 197), maybe confused because of the construction materials: the rammed earth leads them to relate this fortress with the ones in Andalucía and even in southern Morocco.

News about the fortress are dated since 12th Century. It has already been reconquered, and the Episcopal frontiers between Osma and Sigüenza were being outlined. The Pope Inocencio II «gives to [the Bishop of Sigüenza] the tithes, salines, mills and the Serón fortress: "necnon Seronen castellum cum omnibus terminis suis"》 (Zamora Lucas 1969, 30). From that moment on, mentions to the fortress are frequent but always related to disputes and lawsuits both administrative and ecclesiastic. However it is not known whether that «Seronen castellum» is the one we can see nowadays, or a previous construction. That information would only be revealed after an archaeological exploration. There are not building materials either that appear to have been used in a previous construction. Perhaps the stones from glacis were used for the construction of the houses of the village. In any case we cannot confirm that hypothesis.

This fortress is named many times during the late medieval confrontations between Castile and Aragón. That responds to the fact that it is located in one of the busiest routes between Jalón's and Duero's valleys in the "Two Pedros War". The last historical event was the responsible of its downfall: May 10th 1811 French troops set fire to the fortress (Calama y Rosellón 2009, 218). From that moment on its downfall has been unstoppable. The last pull down took place in March 20th 2011 after an intense rain. Unfortunately the last wall was the only one that kept the upper lime mortar rubble finish.

\section{CONSTRUCTIVE FUNDAMENTS OF SERÓN DE NÁGIMA'S FORTRESS}

Nowadays only one out of the two towers of the castle and some of the boundary walls remain standing. It is not known how the interior layout was, however, based on the floor's shape; we can assume it perhaps had an internal courtyard with cistern. This can only be known after detailed archaeological study.

The main constructive characteristic of this fortress is the technique used to build its walls. They were built with rammed earth with a lime mortar coat. The preserved walls have $2.40 \mathrm{~m}$ width at the lower part: about eight Castilian feet. The difference between the lower and the upper parts of the wall, as well as the lack of covering in 
the former, leads us to think that a skirting board protected the lower part of the wall. It could be ashlars masonry. It could have had a $30 \mathrm{~cm}$ width, but we do not know whether it had glacis or not. As in many other cases those stones were probably used in nearby constructions, due to the fact that they were cut accurately.

The upper part of the wall has a $2.7 \mathrm{~cm}$ width, with the mortar external layer, equivalent to nine Castilian feet. It is built by rammed earth levels around $90 \mathrm{~cm}$ high. Batches of compacted earth can be observed. The average thickness is between six and seven centimeters.

The presence of the putlog holes of the wooden cross ties helps us to reconstruct the process of the walls construction. The distance between these putlog holes to each other is about $70 \mathrm{~cm}$. They pass ever from one side of the wall to the other side. In some of them, the superficial sealing remains. This stopper is made with a fill of rubble, gravel, mud and lime. None of them shows any rest of the wooden cross ties. These signs are the negative of the wooden beams used both as wooden cross ties of the formwork as scaffolding to build the walls. Two wooden cross ties' sizes have been documented. The most common size is rectangular: $8 \times 15 \mathrm{~cm}$. The other dimension is square: $10 \times 10$. This difference of sections may result from use of different sized timber by different crews. Over these putlog holes, stones that form the roof of the putlog hole can be observed. These stones

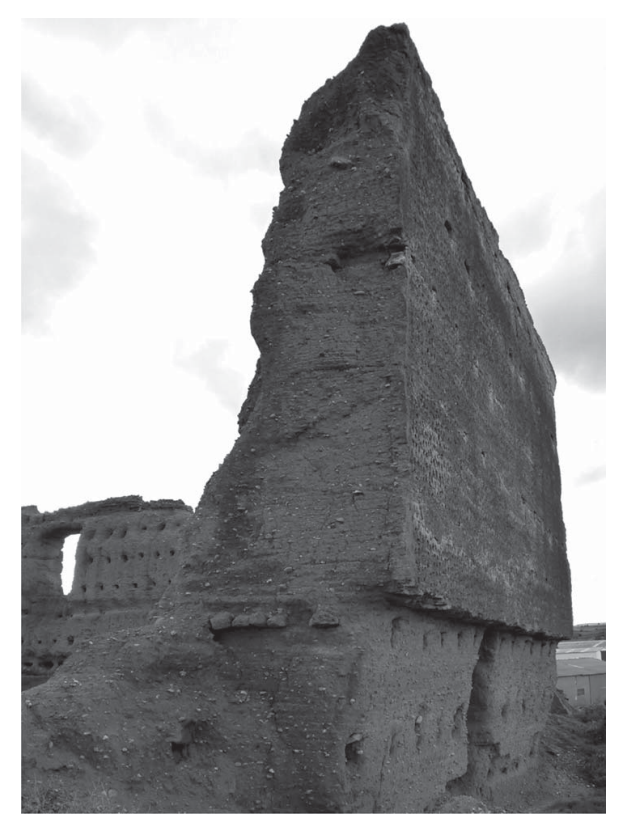

Figure 5. North wall ruins. We can observe the difference of the thickness and the lack of external layer of clay. We can also observe the stones that form the putlog holes in which there were the wood cross ties. separate the wood from rammed earth. Thus the adhesion between both materials is avoided, and the removal of the crossbar as the work progresses is facilitated. We conclude that the elements of wood were reused.

In addition to these elements of wood, of which only the trace remains, others have been found embedded inside the wall. They are wooden rough logs, about 8 to $10 \mathrm{~cm}$ of diameter. They appear mainly in the corners or in encounters between the castle walls. Perhaps, its role was to lock the joint between perpendicular walls. After March 2011 collapse, some rough logs have been found inside the ruins of the rammed earth and has been collected for laboratory analysis.

The wall has an outer layer of lime mortar coat about $10 \mathrm{~cm}$ thick, where we can see the lines of the rammed earth constructive levels. So, we can deduce that this coating was executed on the inner face of the planks forming the cast. The process of reinforcing the rammed earth batches with the successive addition of lime mortar layers at the edge will create an external harder lime crust, commonly known as calicastrado. Looking at the "section" of the wall which the ruin offers, the characteristic saw cross section of this type of caliscastrado coating in each batch - 6 to $7 \mathrm{~cm}$ compacted earth level-is shown. After the removal of the formwork boards, it was leveled and putlog holes from the wooden cross tie were blocked.

The upper part of the walls was finished off with lime mortar rubble, constructed with the same technique of rammed earth formwork. This way, the head of the wall would be protected from impacts and erosion with a more resistant material.

In the walls preserved from the Serón de Nágima castle, we can see several voids. In the western wall there is a big high hole, which could have perhaps been the access to the site. However, the most exceptional holes are some aspilleras or saeteras-loopholes or arrowslit: defensive holes with vertical form - formed by a formwork inside the rammed earth.

To reproduce the building process, the graphical analysis method has been very helpful not only as a mere representation language, but also as a valid tool for the rational interpretation of the building, as reflected in the following figure. This graphical analysis of the construction is based on the traces of the construction processes which remain in its walls.

The encounter among the several phases of the building is done by a inclined joint. It is the result of the shortening of the length of each batch. In this manner ensures proper interlocking between the different phases of work. The elevation of the Figure 6 shows those that are visible outside the western wall. A vertical overlap is seen 
on the left side of the elevation. The inclinations of the different joints are parallel. This indicates that the wall was built from the right (south) to the left (north). On the north wall, inclined joints are also observed in the same direction: from the west to the east. We can know the process of the work by studying the graphic analysis of these joints.

Through the analysis of the constructive signs and joints, we can know the constructive process. Despite the advance state of collapse, inclined joints which mark the advance of the construction can be observed (elevation in Fig. 6 and axonometric view in Fig. 11). Construction started in the south-west tower and continued in the west wall and in the north one. From this tower, the south wall was built. However, between the tower and the south wall there is a vertical joint. There are some putlog holes in the tower which were occulted by the south wall: this indicates that the tower was

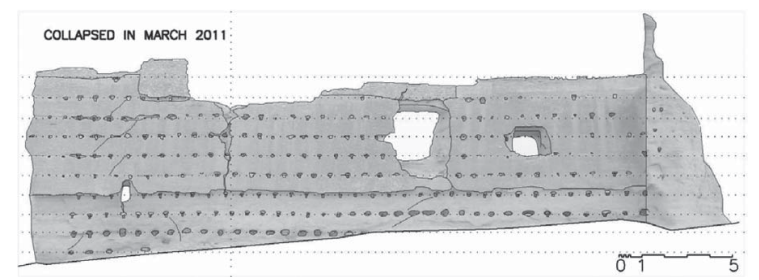

Figure 6. West elevation of the castle.

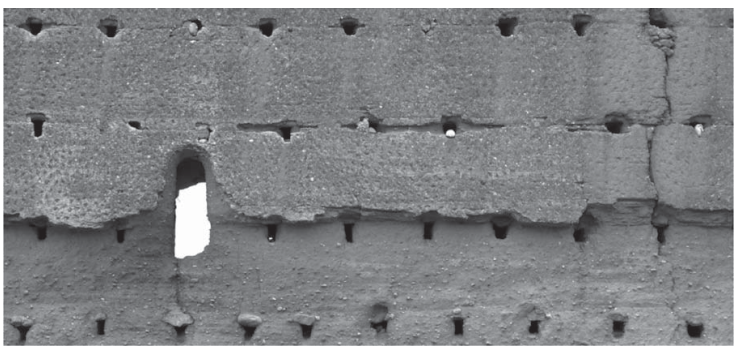

Figure 7. Constructive putlog holes in the west wall.

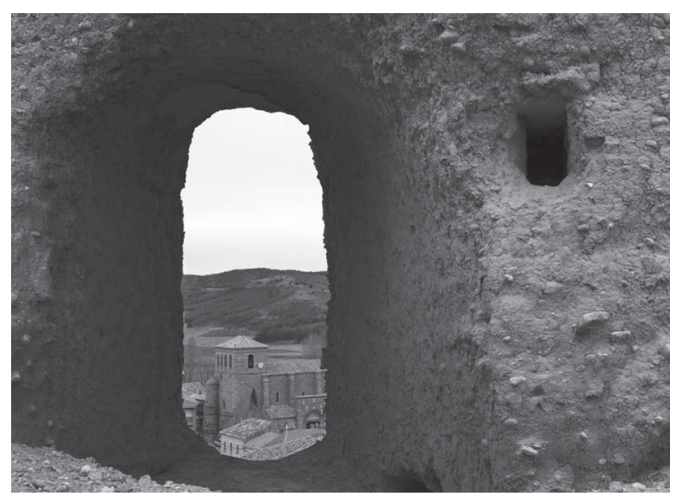

Figure 8. Arrowslit void in the north wall.

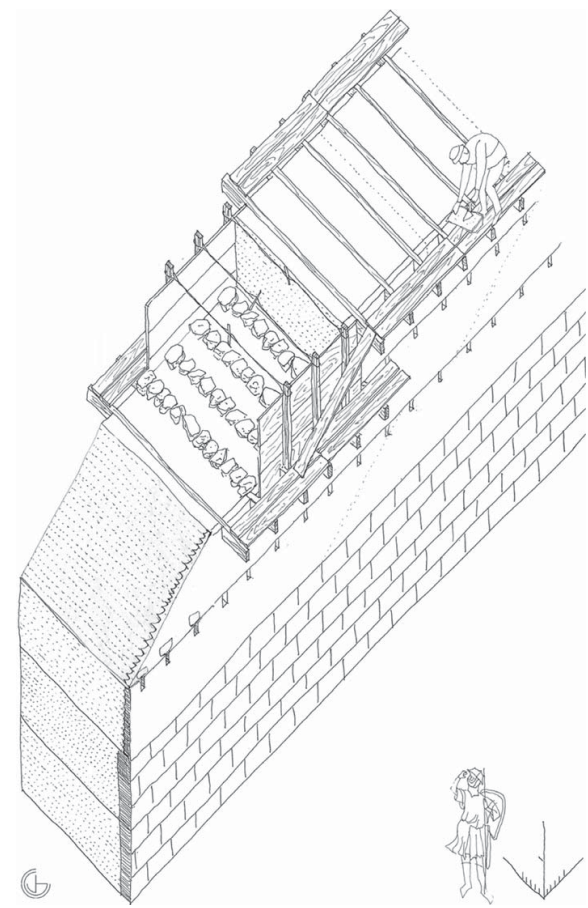

Figure 9. Graphical analysis of the constructive process for the rammed earth walls.

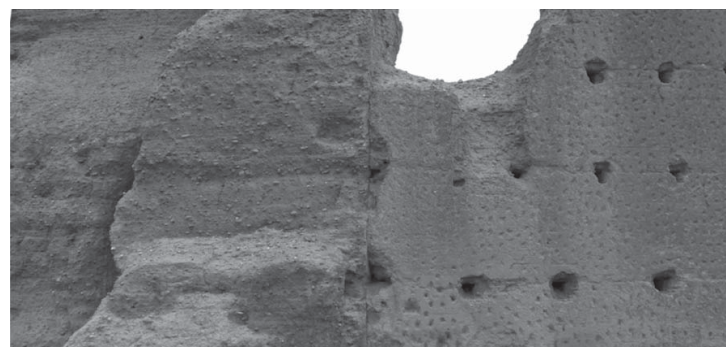

Figure 10. Detail of the joint between the south wall and the south-west tower.

built first and after was erected the south wall. The construction seems to continue towards the east, as the constructive joints show. In the east wall there is hardly any rest and we can not know its constructive process. This complete process is summarized in Figure 11.

The conserved walls have been drawn and a hypothetical reconstruction of Serón de Nágima Castle's complete volume has been designed.

\section{CONCLUSIONS}

The ruin of the fortress of Serón de Nágima is one of the two only complete constructions of rammed earth of the castles in the frontier between the Late Medieval Crowns of Castile and Aragón. The use 


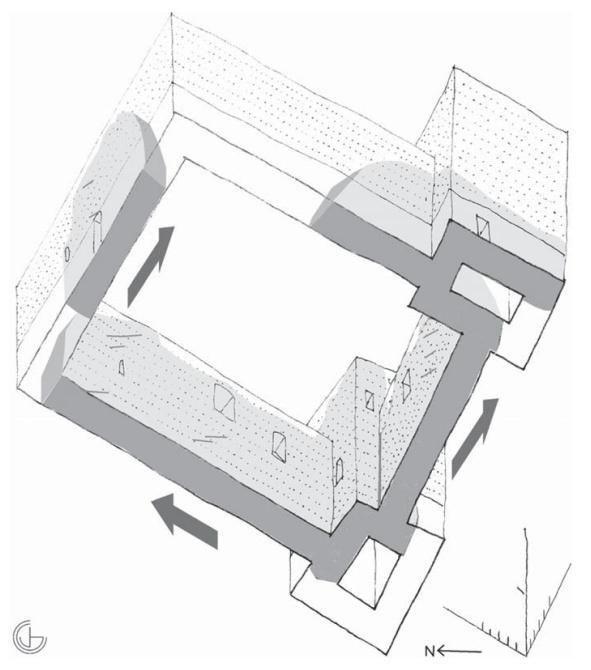

Figure 11. Axonometrical view of the ruins and the hypothetical reconstruction of the rammed earth walls of the castle. Constructive joints - viewed in the ruinshave been designed. The arrows mean the sense of the constructive process. The plan is based in the survey of Lorenzo Celorrio $(2003,347)$ and in author's data took on site.

of rammed earth as a building system in the castle of Serón is why in almost all publications it is referred to as a Muslim construction. It is often compared to those rammed earth fortresses in southern Morocco. However, the analysis of its building process does no state so. The hispanomuslim rammed earth techniques are different from those used in this castle. It is very likely that in the site now occupied by the Serón castle, a Muslim fortification were erected so as to protect the communication with the 10th Century capital city of Medinaceli. Nevertheless, the building we can still see today does not seem to be Islamic characteristics.

From this constructive analysis it is concluded that preserved walls were erected in the same time, with the same material and with the same construction system. The only noticeable difference lies in the two dimensions of the wooden cross ties observed through the sign left by the putlog holes which pass through the walls. The uniform distribution of the two types of beams may indicate the simultaneous work of two groups of workers: while one was building a wall, the other could be building another wall. Despite the ruin state, a constructive and volumetric hypothesis has been designed and graphically analyzed.

\section{ACKNOWLEDGEMENTS}

Laura Yebes Checa and Javier Herrero Cámara have translated the paper in a very short time.
José Antonio García Ares has revised and has advised about several technical terms. Finally, I am very grateful to Laura Herrero Cámara for her support.

\section{REFERENCES}

Bernad Remón, J. 1994. Castillos de Soria. León: Lancia.

Calama y Rosellón, A. 2008. Cronología específica de la Guerra de la Indepen. en Soria y su provincia, incluida la entonces Rioja Soriana (1808-1814). Celtiberia (103): 139-252.

Casa Martínez, C. de la, et al. 1990. Castillos de Soria: aproximación a la arquitectura militar medieval. Valladolid. Univ. Int. Alfonso VIII, Fundación Cánovas del Castillo.

Diago Hernando, M. 1998. El final de la guerra de los Dos Pedros y sus efectos sobre el escenario político regional soriano en la $2^{\mathrm{a}}$ mitad del siglo XIV. Celtiberia (92): 125-156.

Espinosa de los Monteros, J. \& Martín-Artajo Saracho, L. 1974. Corpus de los castillos medievales de Castilla. Bilbao:Clave

Fraile Delgado, M. 2005. Materiales de construcción en los castillos de Castilla y León. PhD Madrid: Univ. Politécnica de Madrid.

Gil Crespo, I.J. 2010. Fundamentos constructivos y análisis patológicos de la arquitectura de tierra en la provincia de Soria. Unpublished manuscript.

Graciani García, A. \& Tabales Rodríguez, M.A. 2008. El tapial en el área sevillana. Avance cronotipológico estructural. Arqueología de la Arquitectura 5: 135-158.

López Guzmán, R. 2000. Arquitectura mudéjar. Madrid: Cátedra.

Lorenzo Celorrio, A. 2003. Compendio de los castillos medievales de la provincia e Soria en el que se incluyen torres y atalayas de lda misma época. Aumentado con las trazas de los ejemplares más representativos y adornado con ilustraciones de aquéllos que conservan restos significativos. Soria: Diputación Provincial de Soria.

Martín García, M. 2009. La construcción del tapial calicastrado en la época nazarí. In $V$ Convención Técnica y Tecnológica de la Arquitectura Técnica (conTART09), Albacete, 25-27 de marzo de 2009. Albacete: COAATB.

Rubio Semper, A. 1990. El Jalón en la Edad Media. In Argente Oliver, J.L. (ed.) El Jalón, vía de comunicación. Soria: Junta de Castilla y León, Museo Numantino.

Tabales Rodríguez, M.A. 2001. Aportaciones de la arqueología medieval al conocimiento de las técnicas constructivas». In Graciani García, A. (ed.), La técnica de la arquitectura medieval, 35-74. Sevilla: Universidad de Sevilla.

Torres Balbás, L. 1949. Arte almohade. Arte nazarí. Arte mudéjar. Madrid: Plus Ultra.

Torres Fontes, J. 1987. El Trat. de Tarazona y la campaña aragonesa en el Reino de Granada (1328-1331). Noel 7-8:3-19.

Zamora Lucas, F. 1969. Dos fortalezas sorianas en la frontera aragonesa: Serón de Nágima y Vozmediano. Castillos de España (64): 29-38. 